\title{
Classical Javanese Dance Learning with Blended Learning
}

\author{
Kusnadi $^{1 *}$, Supriyadi Hasta Nugraha ${ }^{1}$ \\ ${ }^{1}$ Language and Arts Faculty of Universitas Negeri Yogyakarta, Indonesia \\ *Corresponding author. Email: kusnadi@uny.ac.id
}

\begin{abstract}
The purpose of this study is to develop a blended learning model of Javanese classical dance learning particularly in terms of (1) the determination of the blended learning model, and (2) the arrangement of course content. This research was conducted using the ADDIE model of Research \& Development (R\&D). Data were collected using a questionnaire technique and analyzed quantitatively with descriptive statistical techniques complemented by qualitative analysis of input from media expert, material experts and users. This model was implemented in students of the Dance Education study program, the Language and Arts Faculty of Universitas Negeri Yogyakarta in the Surakarta Classical Dance course. The results showed that: (1) $70 \%$ of students preferred the blended learning model where face-to-face lectures and independent learning through e learning were made alternately; (2) The material is compiled from the general, then embodied in detail by parts, and then presented as a whole (referring to elaboration theory), and (3) E-learning materials use various media elements (text, power point slides, pictures, photos, and videos) which are arranged based on learning activities according to student needs. Based on the results can be concluded that blended learning in Javanese classical dance learning can increase efficiency, especially in terms of time use and the level of lecturer involvement in the learning process directly and increasing the effectiveness of learning. However, even though the student's independent learning process is increasing, the role of the lecturer in face-to-face is still important in controlling standard movement techniques and dance expressions.
\end{abstract}

Keywords: Blended Learning; Javannese Classical Dance; Instruction

\section{INTRODUCTION}

Traditionally, classical Javanese dance learning is very dependent on the role of the teacher or lecturer through direct learning. However, if the face-to-face learning time is very limited, and the learning outcomes are less than optimal, other modes are needed.

The development of information and communication technology in education and learning allows an educator to use multi-source and multimedia in learning praxis with various characteristics of objectives and materials, including learning Javanese classical dance. Learning Javanese classical dance, especially at an dance in pairs is quite complex. In this material, students must not only master the movement skills of two characters (usually with different characters) must also understand the other competencies surrounding the dance, namely: (a) historical knowledge and dance development; (b) dance presentation structure; (c) floor design and dance level; (d) dance make-up; (e) dance costume; and (f) dance music. These competencies cannot be fully achieved by direct learning. Based on preliminary observations on priority, it is known that learning is more directed at achieving movement competencies.

As an academic or a prospective teacher, art learning in formal education should not only be limited to the achievement of skills but also the competence of knowledge and attitudes. In the aspect of knowledge, mastery of factual, conceptual, procedural, and metacognitive knowledge related to learning materials is an important competency. In addition, aspects of creativity, independence, and critical thinking in responding to various issues related to learning materials are very important to be developed, of course, with the limited time provided by the curriculum.

Based on the demands of the needs, the challenges ahead, the carrying capacity of educational institutions and the competence of educators, blended learning is an option. With blended learning, learning will be designed in a mix between face-to-face and online, preceded by 
careful analysis of which material should be done faceto-face, and which can be done online. Several previous studies found that blended learning provides easy access, succes, and more varied learning environment [3], and blended learning proved to be an efficient and convenient methodology in terms of enhancing students' level of performance and boost their motivation for sports (ballet) participations [1]. The purpose of this study is to develop a blended learning model of Javanese classical dance learning.

\subsection{Blended Learning}

Blended learning or hybrids learning is a combination of two or more learning models or dimensions. Sing (2003) stated that currently blended learning programs may combine one or more dimensions of blend: (1) blending offline and online learning, (2) blending selfpaced and live, collaborative learning, (3) blending structured and unstructured learning, (4) blending custom content with off-the-shelf content, and (5) blending learning, practice, and performance support. [9]. However, in general the concept that is most widely used is a combination of face-to-face and online learning. Blended learning is essentially a combination of the advantages of face to face learning and virtual learning (e-learning) [6] The existence of blended learning is not only motivated by the difficulty of face-to-face learning, but also the weaknesses of online learning or e-learning.

There are six basic models of blended learning that can be implemented in learning, namely: (1) The FaceTo-Face Driver Model, (2) The Rotation Model, (3) The Flex Model, (4) Online Lab School Model, (5) ) SelfBlend Model, and (6) The Online Driver Model. [10]

The Face-To-Face Driver Model is applied to learning by paying attention to speed differences in learning mastery. Students who complete learning faster are given online learning so as not to get bored, while those who have not achieved completeness are given improvements. Thus only some students take online learning.

The Rotation model is a blended learning approach where students work in a number of different activities or centers, including large group, small group, or peer to peer learning. In the Rotation Model, face-to-face learning is held according to a predetermined schedule then switches to online learning tasks.

The Flex Model is a blended learning approach where students study on the spot with online learning tools, and teachers or lecturers facilitate what is needed.

The online Lab School Model involves students traveling to and attending a school with total online educational delivery for entire courses.

Self-Blend Model is a model that allows students to courses beyond those offered in a traditional setting in a particular school. Students participate in traditional classes but then enroll in courses to complement their regular course.

The Online Driver Model is a model that is the opposite of traditional learning. Learning is completely done online where students are at home.

There are also those who summarize the six models into four models as follows:(1) Rotation model, (2) Flex model, (3) A La Carte Model, and (4) Enreched Virtual Model. Rotation model is a blended learning approach where students work in a number of different activities or centers, including large group, small group, or peer to peer learning. Flex model is a blended learning approach where students study on the spot with online learning tools, and teachers or lecturers facilitate what is needed. The A La Cartel Model is a blended learning model where learning is completely delivered online, and the instructor is not on the student's premises. Enreched Virtual Model is a face-to-face model enriched with online immersion tasks [2].

\subsection{Javanese Classical Dance Learning in Surakarta Style}

The Javanese classical dance- Surakarta style course (dance in pairs) in Dance Education Study Program Curriculum is one of the four Javanese classical dance courses in the Surakarta style which have been arranged in order based on the level of complexity of the material being studied. The first subject is the dance technique, which studies the basics of classical Javanese dance in the Surakarta style. Furthermore, Classical Javanese Dance-1 learns about single dance, Surakarta Classical Javanese Dance-2 learns about paired dance, and Classical Javanese Dance-3 learns about group dance.

From the perspective of material complexity, the Classical Javanese Dance -2 (paired dance) course is in the medium category. The two dance packages studied were the paired female dance and the male pair dance. The paired female dance that is studied as a material representative of the whole paired dance is the Retno Ngayuda dance and the male dance is the Sancaya Kusumawicitra dance. Both of these materials contain the battle between two characters with different dance characters.

The aim of this course is to master the Retno Ngayuda dance and the Sancaya Kusumawicitra dance along with the accompanying knowledge, namely its history, the structure of the presentation of the dance, its make-up, costume, and dance music. Viewed from the perspective of the type of learning from Gagne, this overall material includes several types of learning, namely: (1) learning motor skills, and (2) learning verbal information [4]. But then it can also be developed by learning types of intellectual skills, and learning attitudes by selecting learning strategies. right. 
The main final objective of this course is the mastery of motor skills, namely the skills to dance in pairs. There are several important activities in the process of learning motor skills including dance, namely procedural knowledge of techniques and procedures for how to dance and exercises. Procedural knowledge is directly related to learning scenarios designed by educators or learners so that a dance is easy for learners to learn.

Training is an essential activity in all skills. Motor skills such as flexibility, speed, strength, balance, and coordination of dance movements can only be developed through regular and repetitive exercises. Therefore, in learning dance practices, these exercises should not only be carried out during lectures but also outside lecture hours.

Apart from the two things mentioned above, other important materials are factual knowledge related to the history and creation of dance, make-up and costume, dance accompaniment, conceptual knowledge of dance structures, and procedural knowledge about makeup techniques and wearing dance costumes. Traditionally, all of the learning materials were carried out using a direct instructional approach.

On the other hand, fourth semester students who are taking the Classical Javanese Dance course in the Surakarta style 2 are students who have acquired the basics of Surakarta dance and have studied solo dance in previous courses. This means that in terms of their prerequisite skills, they are sufficient to study more complex material.

\section{METHOD}

\subsection{Development Procedure}

The research approach used in this research is a research and development ( $\mathrm{R} \& \mathrm{D})$ approach. The research procedure used consists of five development steps with the following sequence or development stages: (a) needs analysis, (b) product planning, (c) material collection, (d) initial product format development (programming), (e) testing Alpha, (f) product revision 1, $(\mathrm{g})$ Beta test $(\mathrm{h})$ product revision 2. These stages are in accordance with the framework for determining the blended learning model proposed by Graham (2013), namely explore, explain, and design [5].

\subsection{Research Subjects}

The subjects of this study were divided into two categories, namely as follows: (1) subjects for expert validation (Alpha test), and (2) subjects for field trials (Beta test). The subject for expert validation (Uji Alfa) is a Surakarta-style Javanese classical dance teacher from ISI Yogyakarta. The subjects for the field trial were 4th semester students of the Yogyakarta State University Dance Education Study Program.

\subsection{Data Collection Technique}

There are two kinds of data collection techniques used in this study, namely: (1) a questionnaire to determine the choice of the blended learning model and its components, and (2) the product feasibility assessment scale. The product feasibility assessment scale, in the form of a scale that must be filled in by material / media experts and students when observing products developed using five categories, namely $5=$ very feasible, $4=$ feasible, 3 = quite feasible, 2 = not feasible, and $1=$ very unworthy.

The scale of assessment by material experts consists of four aspects, namely: (a) material truth, (b) material relevance, (c) breadth and depth of material, and (d) material benefits. Each aspect is further broken down into several sub aspects. The rating scale by users (students) consists of several aspects, namely: (a) the truth of the material, (b) the relevance of the material, (c) the breadth and depth of the material, (d) the benefits of the material, (e) the appearance of blended learning, and (f) navigation. The visual aspect of blended learning is further broken down into four aspects, namely: (a) visual aspect, (b) text aspect, (c) sound aspect, and (d) video / animation.

\subsection{Data Analysis Technique}

The data analysis technique used in this research is descriptive statistical data analysis technique equipped with qualitative analysis of the input from blended learning experts, material experts, and users.

\section{RESEARCH RESULTS AND DISCUSSION}

\subsection{Blended Learning Model in Javanese Classical Dance Learning}

Based on the initial assessment, students prefer the Enreched Virtual Model as a form suitable for application in learning Javanese classical dance, but it needs to be modified. This means that online material is not only an enrichment material but also as an initial stimulus before face-to-face learning is carried out. Therefore, there are four blended learning modification models that are offered to students to be selected as a form of implementation of Javanese classical dance learning. The first model, face-to-face is carried out as usual, while online material is only used as complementary material. The second model, $75 \%$ of the materials and assignments are delivered online, while $25 \%$ face to face is used for discussion and evaluation of the movement. The third model, face-to-face and online, is carried out alternately. 
This means that before face-to-face students must study the material online first, then face-to-face, then continue using online material for training guides and deepen the material. The fourth model, online material is studied first to completion, then continued with face-to-face learning.

Table 1. Students' choice of the Blended Learning Model

\begin{tabular}{|c|l|c|c|}
\hline No. & BL Model & $\mathbf{f}$ & $\%$ \\
\hline 1 & The first model & 6 & 15 \\
\hline 2 & The second model & 4 & 10 \\
\hline 3 & The third model & 28 & 70 \\
\hline 4 & The fourth model & 2 & 5 \\
\hline \multicolumn{2}{|c|}{ Total } & 40 & 100 \\
\hline
\end{tabular}

The results of a survey showed that the majority of students $(70 \%)$ chose the third model. Thus, the blended learning model desired by users or students is an alternating model between online and face-to-face.

In addition, the results of the study indicate that the elements of online learning that are deemed necessary are (1) course cover, (2) material maps, (3) formulation of learning outcomes, (4) complete dance video material, (5) dance videos parts (forward piece, core beksan, perangan) for both the Sancaya dance figures and the Kusumawicitra figures, (6) videos of wearing costumes, (7) photos of make-up, (8) photos of parts of costumes, (9) formative tests, (10) ) summative test, (11) material comprehension assignment, (12) material summary, and (13) discussion forum. The elements that are not necessary according to the students are: (1) semester learning plan (because there are already explicitly formulated objectives, (2) announcements, and (3) the task of uploading motion videos for assessment. This means that students want to carry out practical exams still done in person in face-to-face lectures.

\subsection{Arrangement of Course Content on $E$ - Learning}

Based on the needs analysis, the blended learning material is arranged systematically using elaboration theory in the following order (each topic is studied alternately between online and face-to-face).

\subsubsection{Cover Courses}

Contains a photo of the Sancaya Kusumawicitra dance, the name of the course, and lecturer.

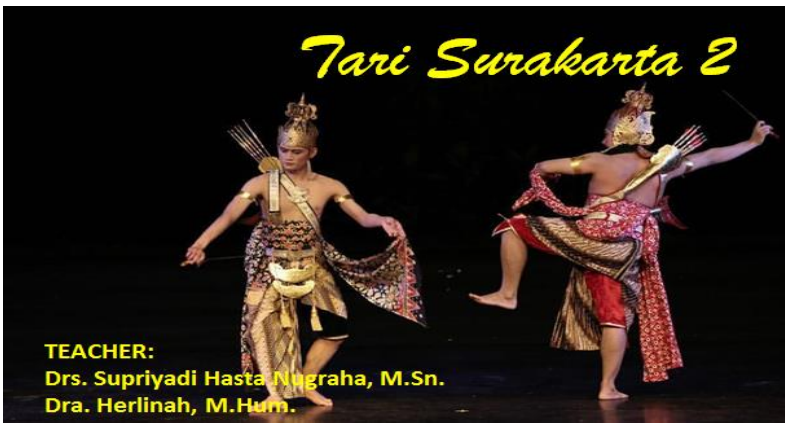

Figure 1 Cover courses.

\subsubsection{Preliminary}

Contains the following material: (1) introduction, (2) learning outcomes, (3) subject matter, (4) learning activities, (5) material outline.

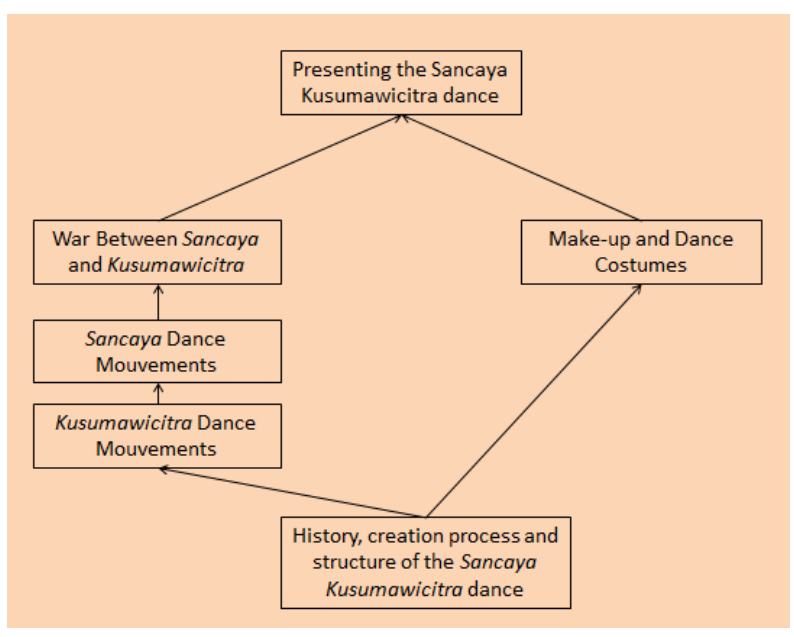

Figure 2 Material outline.

\subsubsection{Topic 1: History, Creation Process and Structure of the Sancaya Kusumawicitra Dance}

Contains the following material: (1) material text of history and creation of Sancaya Kusumawicitra dance, (2) presebtation structure of Sancaya Kusumawicitra, (3) power point slide obout history, creation and structure of the Sancaya Kusumawicitra dance, (4) video of Sancaya Kusumawicitra dance (youtube link), (5) material summary, (6) task, and (7) quiz.

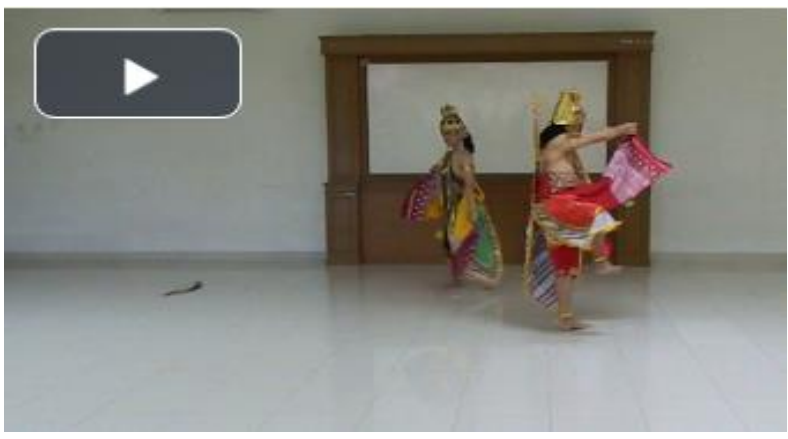

Figure 3 Complete dance videos. 


\subsubsection{Topic 2: Kusumawicitra Dance Mouvements}

Contains the following material: (1) introduction, (2) power point Kusumawicitra dance mouvements, (3) The video of the "maju gendhing" motion of the Kusumawicitra character, (4) The video of the "beksan inti" motion of the Kusumawicitra character, (5) material summary, (6) task, and (7) quiz.

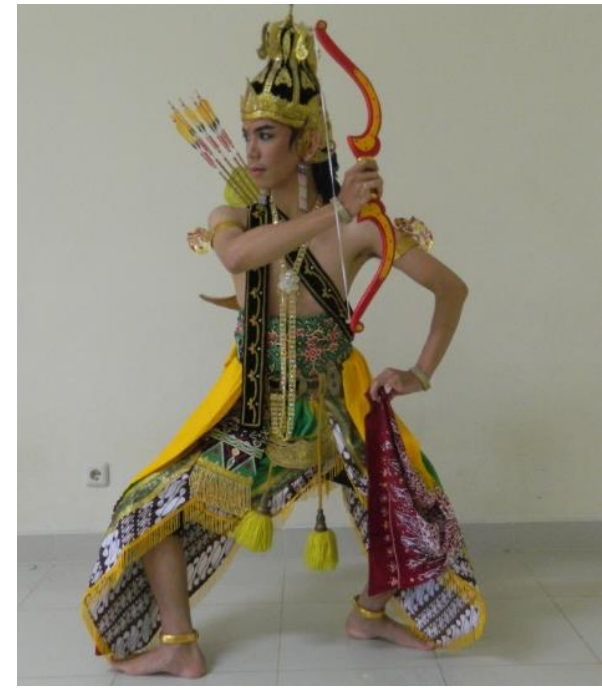

Figure 4 Kusumawicitra dance mouvements.

\subsubsection{Topic 3: Sancaya Dance Mouvements}

Contains the following material: (1) introduction, (2) power point slide of Sancaya dance mouvements, (3) The video of the "maju gendhing" motion of the Sancaya character, (4) The video of the "beksan inti" motion of the Sancaya character, (5) material summary, (6) task, and (7) quiz.

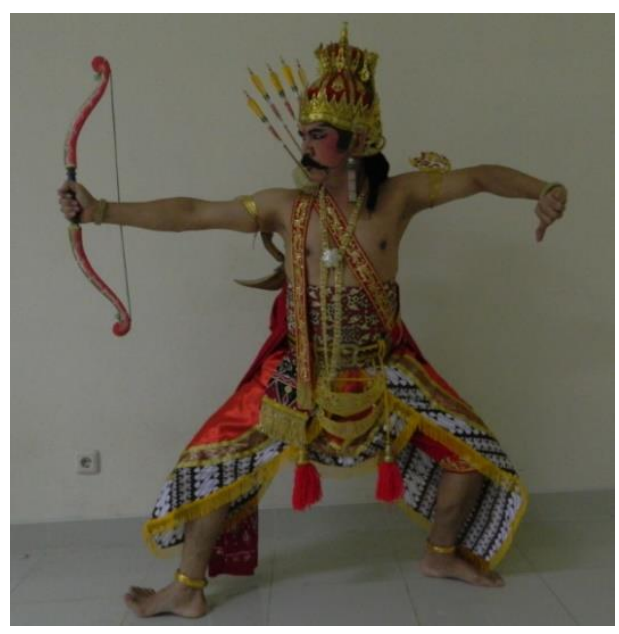

Figure 5 Sancaya dance mouvements.

\subsubsection{Topik 4: War Between Sancaya and Kusumawicitra}

Contains the following material: (1) introduction, (2) "Perang Sikutan" Youtube video link and description, (3) "Perang Adu Keris" Youtube video link and description, (4) "Perang Jeblosan" Youtube video link and description, (5) "Perang Gandewa" Youtube video link and description, (6) material summary, (7) task, and (8) quiz.

\subsubsection{Topic 5 Make-up and Dance Costumes}

Contains the following material: (1) introduction, (2) Kusumawicitra's makeup photo, (3) Sancaya's makeup photo, (4) Kusumawicitra's costumes photo and description, (5) Sancaya's costumes photo and description, (6) Sancaya's and Kusumawicitra's dance property, (7) costume wear video (Youtube link), (8) material summary, (9) task, and (10) quiz.

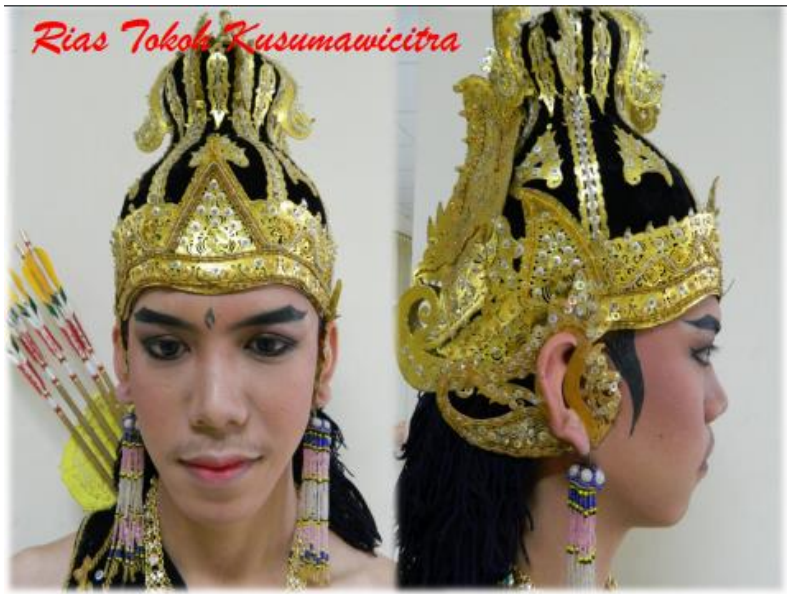

Figure 6 Kusumawicitra's makeup.

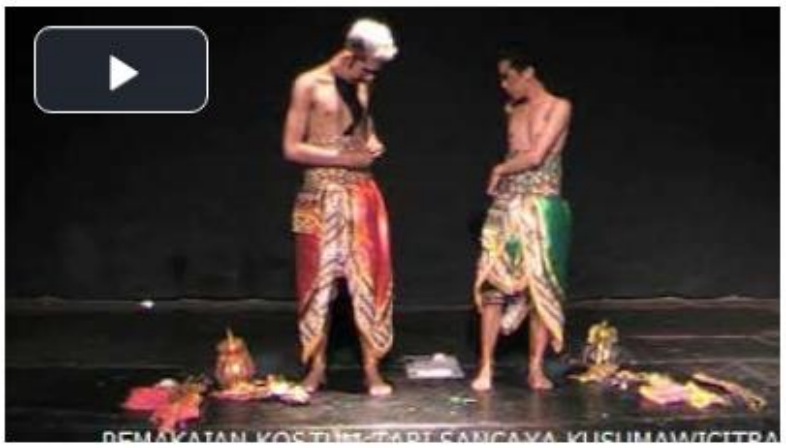

Figure 7 Videos on how to wear costumes.

Based on the characteristics of the arrangement of the material components and their ordering, the arrangement of the content of this course uses elaboration theory [3]. In elaboration theory, so that the material is easy to understand, the learning material is packaged from a general nature, then more specific parts are elaborated. Organizing the material with elaborate theory begins with a very simple introduction and very fundamental ideas in 
the subject matter. Furthermore, each simple material is added with aspects that are more complex and more detailed in the following stages.

These general ideas are manifested in the form of a formulation of learning objectives or outcomes, subject matter which is then visualized in the form of a material map, and steps for learning activities that must be carried out. Another characteristic is that there is a summary at the end of the material and assignments and tests to check the students' level of mastery of the learning outcomes that have been formulated at the beginning of the lesson.

\subsection{Results of Blended Learning Validation}

The validation of the Sancaya Kusumawicitra dance material expert was carried out by Bambang Tri Atmaja, a lecturer in classical Javanese dance in the Surakarta style of the Indonesian Art Institute, Yogyakarta, as well as the son of S. Ngaliman Condro Pangrawit, the creator of this dance. There are four aspects that are assessed for quality, namely: (a) material truth, (b) material relevance, (c) breadth and depth of material, and (d) material benefits. The quantitative score of the results of material validation by dance experts obtained a score as shown in Table 2 below.

Table 2. Material Validation Score by Surakarta Classical Javanese Dance Expert

\begin{tabular}{|c|l|c|l|}
\hline No & \multicolumn{1}{|c|}{ Aspect } & Score & \multicolumn{1}{|c|}{ Status } \\
\hline $\mathbf{1}$ & Material Truth & 94 & Very feasible \\
\hline $\mathbf{2}$ & $\begin{array}{l}\text { Material } \\
\text { Relevance }\end{array}$ & 90 & Very feasible \\
\hline $\mathbf{3}$ & $\begin{array}{l}\text { Extent and Depth } \\
\text { of Material }\end{array}$ & 80 & Feasible \\
\hline $\mathbf{4}$ & Material Benefits & 100 & Very feasible \\
\hline & Mean & 88 & Very feasible \\
\hline
\end{tabular}

Based on the eligibility criteria for the blended learning material that has been set, it is known that in general, the blended learning material is very suitable to be used in learning Javanese classical dance for students of the FBS UNY Dance Education study program. When viewed from an aspect, all aspects are very feasible with a score above 80 . Only one aspect that scores 80 is the depth and breadth of the material. It can be understood that from the aspect of the depth and breadth of the material, this dance still opens the possibility for further exploration, especially in relation to the meaning of dance contained in it.

The validated aspects of the user include: (a) the appearance of e-learning, (b) navigation, (c) the truth of the material, (d) the relevance of the material, (e) the breadth and depth of the material, and (f) the benefits of the material. The results obtained are as follows.
Table 3. Validation Score by Users

\begin{tabular}{|c|l|c|c|}
\hline No & \multicolumn{1}{|c|}{ Aspect } & Score & Satus \\
\hline $\mathbf{1}$ & Material Truth & 92 & Very feasible \\
\hline $\mathbf{2}$ & $\begin{array}{l}\text { Material } \\
\text { Relevance }\end{array}$ & 87 & Very feasible \\
\hline $\mathbf{3}$ & $\begin{array}{l}\text { Extent and Depth } \\
\text { of Material }\end{array}$ & 90 & Very feasible \\
\hline $\mathbf{4}$ & Material Benefits & 89 & Very feasible \\
\hline $\mathbf{5}$ & $\begin{array}{l}\text { The appearance } \\
\text { of blended } \\
\text { learning }\end{array}$ & 83 & Very feasible \\
\hline $\mathbf{6}$ & Navigation & 91 & Very feasible \\
\hline & Mean & 89 & Very feasible \\
\hline
\end{tabular}

Based on the data above, it can be concluded that according to student users, the blended learning that is being developed is declared very suitable for use in all aspects both in appearance, navigation, and material. In general, the blended learning model is very suitable for learning Javanese classical dance in Surakarta style, especially in paired dance material.

\subsection{Implementation in Learning}

then tried out in real learning. The results that can be observed during the trial process are an increase in student understanding of the knowledge of the dance being studied, the structure of dance presentation, and memorization of dance movements. From the aspect of the process of training in dance movement skills, students are greatly helped by the existing videos on e-learning which have been packaged in university's e-learning. Face-to-face learning activities are mostly used to work on correct movement techniques and dance expressions. In addition, the teaching and learning process becomes more efficient both in terms of learning time and the level of lecturer involvement.

\section{CONCLUSION}

Based on the results of the above research, it can be concluded that blended learning in Javanese classical dance learning can increase efficiency, especially in terms of time use and the level of lecturer involvement in the learning process directly and increasing the effectiveness of learning. However, even though the student's independent learning process is increasing, the role of the lecturer in face-to-face is still important in controlling standard movement techniques and dance expressions.

\section{REFERENCES}

[1] M. Bayyat, Blended Learning: A New Approach to Teach Ballet Technique for Undergraduate Students, Turkish Online Journal of Distance Education 21(2) (2020) 69-86. 
[2] Brooks, Four Keys to Success Using Blended Learning Implementation Models. http://lexialearning.com

[3] C. Dziuban, C. R. Graham, P. D. Moskal, A. Norberg, and N. Sicilia, Blended learning: the new normal and emerging technologies. International Journal of Educational Technology in Higher Education 15(1) (2018) 3.

[4] R. M. Gagne, Learning outcomes and their effects: Useful categories of human performance. American psychologist 39(4) (1984) 377.

[5] C. R. Graham, C. R. Henrie, A. S. Gibbons, Developing models and theory for blended learning research, Blended learning: Research perspectives, 2, 2013, pp. 13-33.

[6] U. Köse, A blended learning model supported with Web 2.0 technologies, Procedia-Social and Behavioral Sciences 2(2) (2010) 2794-2802.

[7] Reigeluth, C.M. 1983. "The Elaboration Theory of Instruction" on Reigeluth, C.M. (ed) .1983. Instructional Design Theoris and Models. New Jersey: Lawrence Erlaboum Associates.

[8] A. P. Rovai, H. M. Jordan, Blended learning and sense of community: a comparative analysis with traditional and fully online graduate courses, International Review of Research in Open and Distance Learning, Vol. 5, Number 2, 2004, pp. 1492-3831

[9] H. Singh, Building effective blended learning programs, Educational Technology-Saddle Brook Then Englewood Cliffs NJ- 43(6) (2003) 51-54.

[10] H. Staker, M. B. Horn, Classifying K-12 blended learning, Innosight Institute, 2012. 